\title{
VÁLLALKOZÁSFEJLESZTÉSI MENTORÁLÁSI FOLYAMAT A KARMESTER SZEMSZÖGÉBŐL, AVAGY MILYEN ELVÁRÁSOKNAK KELL MEGFELELNIE EGY MENTORNAK ÉS HOGYAN TUD SIKERESEN VEZETNI EGY FOLYAMATOT?
}

Clutterbuck (2005) - a vállalkozásfejlesztési mentorálási folyamatok egyik legismertebb kutatója - szerint szükéges lenne egy olyan, generikus vállalkozásfejlesztési mentorálási standardlista kialakítására, amely kisebb-nagyobb változtatásokkal, de alkalmas lenne valamennyi, ilyen jellegű folyamat esetén alkalmazásra, ezzel egyfajta mankót és keretrendszert biztosítva a mentorok és vállalkozásfejlesztési mentorálási tevékenységet koordináló szervezetek számára. Jelen tanulmány arra keresi a választ, hogy melyek azok a tényezők - kompetenciák, tulajdonságok és attitűdök - amelyek elvártak a mentortól egy sikeres vállalkozásfejlesztési mentorálási folyamat során.

Kísérlet már történt ilyen lista összeállítására, de egységesen elfogadott keretrendszer még nem létezik. Létrehozása azonban több szempontból előnyös lehet: egyrészt, mert a vállalkozásfejlesztési mentorálási porgramok többnyire fiatal és ezáltal könnyen sebezhető, még kevés tapasztalattal rendelkező embereknek szólnak, így jövőjük alakulásának tekintetében a folyamatban részt vevő mentorra is nagy felelősség hárul, másrészt a standardok kialakítása minőségbiztosítási kérdéseket is felvet, harmadrészt pedig a vállalkozásfejlesztési mentorálási tevékenység gyors terjedése és növekedése megköveteli és felhívja a szabályozás fontosságára is a figyelmet.

A kérdőíves kutatáson alapuló elemzés rámutat, hogy a magyar vállalkozásfejlesztési ökoszisztéma résztvevői szerint a sikeres folyamatvezetéshez tizennyolc, hat faktorba sorolható olyan tényező (mentori kompetencia, attitűd vagy tulajdonság) szükséges, amelyek modellbe rendezve hozzájárulnak az eredményes vállalkozásfejlesztési mentorálási folyamatok vezetéséhez.

Kulcsszavak: vállalkozásfejlesztés, vállalkozásfejlesztési mentorálás, vállalkozásfejlesztési mentor, mentori kompetenciák

$\mathrm{D}$ inamikusan változó világunkban, ahol a KKV-k dominanciája figyelhető meg, és ahol a versenyelöny tényezőjeként a különböző szervezetekben, illetve vállalkozásokban tevékenykedő munkatársak, azaz az emberi erőforrás és annak kvalifikációja nevezhetők meg, sem egyéni, sem szervezeti siker nem érhető el a szükséges, rugalmas felkészülés, vagy pedig a megfelelő fokú elkötelezettség kialakítása nélkül. A jövő vezetői nyitottak és érdeklődők, mindent megtesznek annak érdekében, hogy szélesítsék látókörüket társadalmi és üzleti téren egyaránt. Jellemző rájuk az a törekvés, hogy folyamatosan új ismereteket sajátítsanak el, ezzel alkalmazkodó képessé válva a folyamatosan változó körülményekhez.

Mindehhez azonban több forrásból és tudományterületről származó ismereteket kell alkalmazni (Iniguez, 2008). Ezen ismeretek számos helyről származhatnak: a szervezetek elsősorban a szakmai képzést és a vezetöképző programokat támogatják, holott sokszor hallani kompetencia alapú megközelítésről is, ami azonban eddig kevésbé valósult meg, pedig a vállalkozások esetén ez lenne a kívánatos. Nincsenek jobb és rosszabb módszerek, sikeresebbek vagy sikertelenebbek, a fontos az, hogy a fejlesztési tevékenység esetén az adott szituációban és az adott személyhez legjobban illöt (illőket) alkalmazzuk. Vállalkozások esetén ez kiemelten igaz: a vállalkozó személyiségétől, tapasztalatától, a vállalkozás profiljától, célpiacától függően merőben eltérő típusú és mélységü segítségre lehet szükség. Egy induló, illetve jelentős növekedési potenciál előtt álló kis- vagy közepes, illetve családi vállalkozás fejlesztésére számos lehetőség adott. De, mint azt az előzőekben láttuk, a gazdálkodó szervezetek versenyképességének újszerü tényezőjeként az emberi erőforrást és annak szervezetben betöltött helyét, szerepét definiáltuk. Ezen analógia mentén a vizsgált vállalkozások esetében is a hangsúlyt a munkaeröre, így sok esetben az alapító tulajdonosra, ötletgazdára szükséges helyezni. Az ő képzése, fejlesztése számos módon megvalósulhat: részt vehet valamilyen hagyományos értelemben vett (tovább) képzésen, amely lehet iskolarendszerü, felnőtt, illetve e-learning alapú képzés, továbbá vezetöi vagy csoporttréningen való részvétel, terápiás célzatú folyamat, tanácsadás, mediáció, coaching, illetve mentorálás.

A különböző képzési és fejlesztési tevékenységek hozzájárulhatnak a vállalati versenyképesség fokozásához, az emberi erőforrás, mint újszerü versenyképességi tényező potenciáljának minél jobb kiaknázásához. Savaneviciene (2008) megállapítása szerint e fejlesztési tevékenységek mind egyéni, mind szervezeti szinten megjelenhetnek, és olyan módszereket foglalhatnak magukba, amelyek a graduális képzés, a tréningek és szemináriumok, a munkahe- 
lyen történő tanulás, coaching és önfejlesztés témakörébe sorolhatók.

A vállalkozók fejlesztése kapcsán gyakorta említik a vezetőfejlesztést, mint tevékenységet (Bolden - Terry, 2000; Bolden, 2007; Leith, 2009; Stewart, 2009). Számos forrás mutat rá arra, hogy a vállalkozók fejlesztése nem más, mint vezetőfejlesztés. Baumol (1968) korai munkásságában azt a megállapítást tette, hogy egy növekedésközpontú világban megpróbálhatjuk megtanulni azt, hogyan kell és lehet stimulálni a vállalkozási hajlandóságot és aktivitást, de a megoldásokat keresni kell. Az ezredfordulót követően még mindig helytálló az a megállapítás, hogy a vezetőfejlesztés terén nincs egységes álláspont. Egymás mellett párhuzamosan figyelhető meg két irány: egyes szervezetek esetén a vezetőfejlesztés szükségletalapon, tervezés nélkül, ad-hoc módon történik; míg más esetekben azt a teljes személyre szabás jellemzi. Az optimális megoldás eléréséhez fontos lenne, hogy mindenki azt kapja, amire szüksége van. (Petrányi, 2013) Erre pedig a mentorálás - mint a vezetőfejlesztés és a karriermenedzsment eszköze - megfelelő tevékenység (McCauley - Van Velsor, 2004; Chuck - Yanbo, 2014).

A fejlesztéssel foglalkozó pszichológusok többsége egyetért ugyanakkor abban, hogy a vezetőket nem annyira a vezetési filozófiájuk, a személyiségük, vagy vezetési stílusuk különbözteti meg egymástól, hanem inkább belső 'cselekvési logikájuk' - ahogyan értelmezik környezetüket, és ahogyan reagálnak, amikor hatalmuk és biztonságuk veszélybe kerül. Mindazonáltal viszonylag kevés vezető próbálja megérteni a saját cselekvési logikáját, és még kevesebb fedezte fel megváltoztatásának lehetőségét. Ebben a folyamatban van jelentősége a mentorálásnak (Rooke - Torbert, 2005 p. 7.).

Coachinggal, mentoring folyamatokkal, reportinggal, illetve feedback adással és kapással optimalizálható a vállalkozási tevékenységhez magához, valamint egy vállalkozás vezetéséhez szükséges tudás jobb felhasználása (Gaál et al., 2012). Az akadémiai szintű tudást és a való világot szükséges lenne összekapcsolni, azaz a pedagógia elméleteket ötvözni kellene az üzleti metódusokkal és modellekkel (Robinson - Haynes, 1991 p. 61.) Ehhez pedig a mentorálást - hasonlóan a rokon szakmának számító, de mégis jelentős eltéréseket magában foglaló coachinghoz -, elsőszámú lehetőségként említik, mint a vállalkozásfejlesztést leghatékonyabb segítő tevékenységet (Terjesen Sullivan, 2011; Leferbre - Redien - Collot, 2013).

További, megválaszolandó kérdés lehet annak tárgyalása is, hogy mi állhat a mentorálás, mint fejlesztési tevékenység elismerése és széles körü alkalmazásának, elterjedésének - illetve azok hiányának - hátterében. Az egyik alapvető problémát magának a fogalomnak nem ismertsége jelenti. És habár a mentorálás szerepéről a szakirodalomban rendelkezésre álló információ kevés található, az kijelenthető, ennek ellenére a fejlesztő és segítő foglalkozások közül e tevékenység fontosságát és hasznosságát sok forrás kiemeli (Lutz et al., 2015 p. 38.).

A mentorálás népszerüségét tekintve gyorsan növekszik, mint a fiatal vállalkozók által igénybe vehetetö, testreszabott támogató és segítő tevékenység (St. Jean
- Audet - Courtet, 2009b, p. 148.). Csapó (2009) értekezésében, amely a gyorsan növekvő kis- és középvállalkozások jellemzőit és fejlesztési lehetőségeit vizsgálta Magyarországon, azt a megállapítást tette, hogy a nyugati piacgazdaságokban, de fóként az angolszász országokban müködnek olyan tanácsadói programok, amelyekben már sikeres, befutott 'gazellák' alapítói, vezető vállalkozói adnak tanácsokat induló vagy a növekedés elején álló cégek számára (Csapó, 2009, p. 144.). Ennek előnye, mint arra Kállay és Imreh is utal, hogy az ilyen 'befutott' vállalkozások vezetői, tulajdonosai rendelkeznek tapasztalattal, tudják milyen makrokörnyezetben és milyen kihívásokkal kerülhet szembe egy induló kisvállalkozás (Kállay - Imreh, 2004), így hatékonyan lehetnek segítségére, támogathatják tanácsaikkal a piacon most megjelenni kívánó, induló vállalkozásokat, azaz a viszonylagos ismeretlenségen való túllendülést segítik. A vállalkozások induló szakaszában a legtöbb külső segítség a mentortól kapható (Vecsenyi - Petheö, 2017, p. 73.), amennyiben azt jól sikerül kiválasztani.

\section{A vállalkozásfejlesztési mentorálási folyamat definíciója}

A vállalkozásfejlesztési mentorálási folyamat magába foglal egy támogató kapcsolatot a tapasztalattal rendelkező vállalkozó (mentor) és a kezdő (fiatal) vállalkozó (mentee) között, abból a célból, hogy utóbbi személy személyes fejlődését elősegítsék (St. Jean - Audet, 2009),

hiszen a vállalkozóknak mindenkinél inkább szükségük van mentorokra, az elöttük álló feladatok komplexitása és kiterjedtsége miatt (Krueger - Wilson, 1998). A vállalkozásfejlesztési mentorálási tevékenység szemléletét tekintve, figyelembe véve annak alapvető célját, azaz, hogy támogatást és segítséget biztosítson, valamint facilitálja az ötletek és információk megosztását, ezzel elősegítve a fiatal vállalkozók túlélését és növekedését az üzleti világban (Kantor, 2001, p. 43.), ugyanezt támasztja alá.

A vállalkozásfejlesztési mentorálási folyamat egyik kulcstényezője az, hogy a vállalkozói lét komplexitásához, sokszínű tevékenységének ellátáshoz, illetve az ezekhez kapcsolódó feladatokkal való 'megküzdéshez', hogyan tud hozzájárulni a mentor, mennyiben tudja segíteni a mentoráltat. A mentorálás minden kétség nélkül alkalmas formája a vállalkozók támogatásának, mivel lehetővé teszi saját menedzsment képességeik fejlesztését, a tanulást akciókon keresztül, mindezt egy kiterjedt üzleti tapasztalatokkal rendelkező, támogató segítő közbenjárásával (St. Jean - Audet, 2009, p. 150.). Ezen támogatási folyamatra pedig a visszajelzések szempontjából is szükség van. Ugyanakkor van a vállalkozásfejlesztési mentorálási folyamatnak egy másik, nemcsak a business oldalt támogató megközelítése is: adódhatnak olyan helyzetek, amikor a mentorált személyes, érzelmi támogatást, ezáltal pedig kognitív fejlődésének elősegítését várja a folyamattól. A vállalkozások esetében megfigyelhető, különböző területen adódó szűk keresztmetszetek - mint idő, anyagi és energia ráfordítás - és a felmerülö kérdések, valamint elakadások komplexitása következtében, a hagyományos 
oktatás és tradicionális tanácsadói tevékenység nem jelentenek kielégítő megoldást. Ilyen esetekben a mentorálás tudástranszfer funkciója, valamint kompetenciafejlesztő volta következtében az elemzés-tervezés tevékenységének során, valamint a vállalkozói, személyes hatékonyság fejlesztésében jelenthet megoldást. Ezen irány teljessé tételéhez pedig elengedhetetlen az úgynevezett soft-skillek fejlesztése is. A vállalkozói skillek fejlesztése összefüggésben van a vállalkozó szociális nyelvének fejlesztési folyamatával, mivel ez segít kialakítani a személyes teóriákat, a gondolkodást és az akciót (Rae, 2000). Eredményeképpen minél szélesebb tárházból és ismeretanyagból, sokszínübb tapasztalatból meríthet a mentorált, annál inkább lesz rugalmas az előtte álló kihívásokkal szemben. Más megközelítés szerint ugyanis a vállalkozásfejlesztési mentorálás olyan kiegészítő, fejlesztő tevékenység, ami az egyént körülvevő, elsődleges tanulási környezethez kapcsolódik, és amely a hagyományos stratégiákat kiegészítve a nagyobb rugalmasság lehetőségét kínálja (Gay Stephensson, 1998)

Jelen tanulmányban a vállalkozásfejlesztési mentorálási folyamatot úgy értelmezem, mint egy mentális modell kialakításának első lépését. Ez a mentális modell teszi lehetővé a mentorált (fiatal vállalkozó) számára, hogy saját ötletéből kiindulva, arra alapozva vállalkozói tevékenységet végezzen, és e tevékenység végzése során felmerülő kihívásokat a lehető leghatékonyabban kezelje. A mentorálási folyamat ennek alapján nem lesz más, mint egy kevésbé tapasztalt és egy tapasztalt résztvevő közötti interakció beindítása, a közös gondolkodás kezdete, amelynek célja a mentee vállalkozói kompetenciáinak fejlesztése. Ugyanakkor a mentorálási folyamat egy biztonságot nyújtó környezetben a pártfogolttal való elkötelezett, folyamatában vele foglalkozó, minden segítséget, támogatást és visszajelzést megadó, bizonyos, előre meghatározott keretek között végbemenő tevékenységsorozat, amelynek célja a mentee A-ból B-be, azaz a kiindulási ponttól a kitűzött állapotig történő eljuttatása az úton való végig kísérés által. Feltételezésem ugyanakkor az, hogy nem minden mentorálási folyamat képes ugyanazokat a tanulási kimeneteleket, hasznokat, elönyöket biztosítani (Zsigmond, 2017, p. 590.). Hogy mik a befolyásoló tényezők, még vizsgálatra szorulnak. Mint azt St. Jean és Audet is megállapítja: az biztos, hogy egyes tényezők mint a mentor szerepei, a mentorálási ülések gyakorisága és hossza, valamint a résztvevők pszichológiai jellemzői - befolyásolják a tanulást, de a témában további, mélyebb vizsgálatok szükségesek (St. Jean - Audet, 2009).

\section{A mentorálási folyamat, szereplői és a mentorral szemben támasztott elvárások}

Bármely mentorálási folyamatra jellemző a diadikusság, azaz kétirányúság (Kram, 1985; Waters et al., 2002; Alfred - Garvey, 2010; Myers, 2016). Mivel ez a kétirányúság emberek kapcsolódásából és interakciójából áll, megítélése sok esetben szubjektív. Ennek ellenére bizonyára vannak olyan, mind a mentorral, mind a mentee-vel szemben elvárt tulajdonságok, attitüdök, kompetenciák, amellyel a folyamatban résztvevőknek feltétlen rendelkeznie kell. Kiinduló pontnak tekintve, hogy a mentorálás folyamata egy kétszereplős tevékenység, amelyben a mentor, mint egy professzionális szolgáltatás nyújtója, a mentorált pedig, mint annak igénybe vevője van jelen, és a mentor definíció szerint rendelkezik tapasztalattal és a folyamat szempontjából fontos irányítási, facilitálási képességgel, elsősorban a mentor folyamathoz való kapcsolódás kerül vizsgálatra.

A mentorral szemben támasztott követelmény- és elvárásrendszer megvizsgálásához, feltétlenül szükséges annak tisztázása, hogy vállalkozásfejlesztési szempontból kit tekintünk mentornak. Jelen tanulmány során vállalkozásfejlesztési mentor alatt értem azt a tapasztalattal rendelkező, nyitott, tudását megosztani szándékozó és tudó, üzleti életben jártas segítőt, aki egy kétirányú kapcsolaton keresztül hozzájárul egy kevésbé tapasztalt (a vállalkozói lét elején járó, vagy elakadással küzdő, esetleg növekedési kérdés elött álló) vállalkozó céljainak eléréséhez tudástranszferen és támogatáson keresztül, miközben a mentorált szakmai ismeretei bővülnek, személyes képességei fejlődnek.

Figyelembe véve, hogy a mentor feladata meglehetősen komplex, az e tevékenység végzéséhez szükséges kompetenciák, tulajdonságok listájának összeállítása is szerteágazó és bonyolult. Ezt tovább bonyolítja, hogy a folyamatvezetés nem laboratóriumi körülmények között, hanem egy gyorsan változó környezetben történik, így a szituáció és a kontextus ülésröl ülésre, vállalkozóról vállalkozóra változik, így tehát nem elegendő a mentorált igényeinek megfelelő tevékenységet kiválasztani, de azt a kontextus adta elvárásokhoz is igazítani szükséges (Clutterbuck - Lane, 2005). Ez az igazodás pedig nem elsősorban és kizárólagosan az input tényezőket (mentor háttere és tapasztalata) jelenti, hanem sokkal inkább azt, hogy adott szituációban hogyan jár el, milyen megoldási mintákat alkalmaz (St. Jean - Audet, 2009/b).

A szakirodalom feldolgozása során számos, a mentorral szembeni, sikeres folyamatvezetéssel kapcsolatosan támasztott követelményt azonosítottam, amelyeket a könnyebb átláthatóság végett, jelentéstartalmuk szerint öt csoportba soroltam. E csoportokat mentori attitüd (1), elméleti ismeretre vonatkozó tényezők (2), tulajdonságok (3), képesség és kompetenciák (4), valamint egyéb, a folyamatvezetéshez nélkülözhetetlen jellemzők (5) névvel illettem. Az egyes csoportokba számos tényezőt: kompetenciát, attitüdöt és tulajdonságot soroltam be. (1. táblázat)

akirodalom abban egyetért, hogy a mentorálási folyamat hatékonyságának megítélésekor figyelemmel kell lenni a mentor jellemzőire (Mullen, 1994), abban azonban nincs egyetértés, hogy ezek a jellemzők mit takarnak pontosan. A mentorral szemben támasztott követelmények figyelembevételekor megállapítható, hogy egyes elméletek kulcsfontosságú tényezőket emelnek ki $(L d$. 1. táblázat), míg más szerzők séma mentén, komplex modellként ismertetik az elvártakat. Mivel jelen tanulmány célja is egy olyan, hazánkra jellemző modell megalkotása volt, amely előrevetíti a sikeres folyamatvezetést, így az elvárások rendszerének modellben történő bemutatása két meg- 
A mentorral szemben támasztott követelmények rendszere

\begin{tabular}{|c|c|c|}
\hline \multicolumn{2}{|r|}{ Tényezó } & Szerzö \\
\hline \multirow{4}{*}{ 莺 } & Bizalom és hit & Starchevich, 2009 \\
\hline & Céltudatos & Clutterbuck, 2005 \\
\hline & Nyitott & Clutterbuck, 2005; Starchevich, 2009; Nagypál, 2010; Menges, 2015 \\
\hline & Pozitív attitüd & Clutterbuck, 2005; Starchevich, 2009; Bencsik, 2012; Memon, 2013 \\
\hline \multirow{5}{*}{ 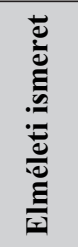 } & Azonos iparági ismeret & Bisk, 2002; Deakins, 1997 \\
\hline & Általános üzleti tudás & Wilson, 1999; Clutterbuck, 2005; Szádvári, 2011; Menges, 2015; Heathfield, 2016 \\
\hline & Közgazdasági ismeret & Bencsik, 2012; Filius, 2012 \\
\hline & $\begin{array}{l}\text { Más fejlesztő tevékenységbeli } \\
\text { ismeret }\end{array}$ & Kram, 1985; Clutterbuck, 2005; Smith, 2005;Szádvári, 2011 \\
\hline & Szervezeti ismeretek & Smith, 2005; Szádvári, 2011; Heathfield, 2016 \\
\hline \multirow{7}{*}{ 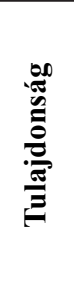 } & Elkötelezettség & Clutterbuck, 2005; Szádvári, 2011; Smith, 2013; Roll, 2015; Heathfield, 2016 \\
\hline & Empátia & Clutterbuck, 2005; Smith, 2005; Conor, 2007; Starchevich, 2009; Roll, 2015; Palmer, 2016 \\
\hline & Extraverzió & Menges, 2015 \\
\hline & Humor & Clutterbuck, 2005 \\
\hline & Konzisztencia & Bencsik, 2012 \\
\hline & Önzetlen & Clutterbuck, 2005; Starchevich, 2009 \\
\hline & Öszinte & Conor, 2007; Starchevich, 2009; Bencsik, 2012; Rácz, 2014 \\
\hline \multirow{9}{*}{ 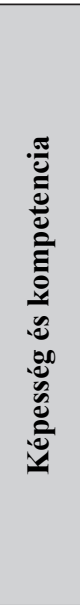 } & Érzelmi intelligencia & Berman - West, 2008; Heathfield, 2016 \\
\hline & Folyamat- és projektorientáltság & Katherndahl, 2011; Filius, 2012 \\
\hline & Integritási képesség & Heathfield, 2016 \\
\hline & Keretek kialakításának képessége & Clutterbuck, 2005 \\
\hline & $\begin{array}{l}\text { Kommunikációs képességek, } \\
\text { beleértve a visszajelzés adásá- } \\
\text { nának és aktív hallgatásnak a } \\
\text { képességét }\end{array}$ & $\begin{array}{l}\text { Clutterbuck, 2005; Smith, 2005; Jones - Spooner, 2006; Conor, 2007; DeLong, 2008; Star- } \\
\text { chevich, 2009; Nagypál, 2010; Zsigmond, 2011; Bencsik, 2012; Dávid, 2014; Rácz, 2014; } \\
\text { Roll, } 2015\end{array}$ \\
\hline & $\begin{array}{l}\text { Önismeret, önkritika és önfej- } \\
\text { lesztés képessége }\end{array}$ & Gibbs, 2000; Clutterbuck, 2005; Smith - Jenetsch, 2008; Szádvári, 2011; Rácz, 2014 \\
\hline & $\begin{array}{l}\text { Rendszerben történő gondolko- } \\
\text { dás }\end{array}$ & Clutterbuck, 2005; Starchevich, 2009; Rácz, 2014 \\
\hline & $\begin{array}{l}\text { Tudásátadási képesség és hajlan- } \\
\text { dóság }\end{array}$ & Roche, 1979; Kiss, 2003; Zsigmond, 2012; \\
\hline & Türelem & Starchevich, 2009 \\
\hline \multirow{3}{*}{ 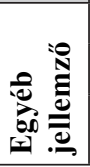 } & Hitelesség & Hollister - Sutter, 2001; Kunos, 2011; Nagypál, 2016; Palmer, 2016 \\
\hline & Network-höz való hozzáférés & Clutterbuck, 2005; Bencsik, 2012; Rácz, 2014; Heathfield, 2016 \\
\hline & Szerepmodell & Clutterbuck, 2005; Noor, 2010; Kerry - Mayers, 2013; Dávid, 2014; Mitchell, 2015 \\
\hline
\end{tabular}

közelítés, az EMCC (Európai Mentorálási és Coaching Tanács) ajánlása, valamint Clutterbuck (2017), a folyamat fázisaihoz rendelt szempontrendszere alapján történik.

A Tanács által megfogalmazott első kompetencia az úgynevezett 'megértő én' (1), amely demonstrálja a saját értékekkel való tisztában létet, az egyéni hitet és viselkedést, ugyanakkor feltételezi, hogy a mentor képes felismerni, hogy ezek milyen hatással vannak a folyamatra és ennek megfelelően kezelni is tudja azokat. Másrészről elvárt a mentorral szemben, hogy elkötelezett legyen az önfejlesztés iránt (2), feltárja és fejlessze saját gyakorlatát és elméleti tudását, ezáltal pedig biztosítsa a szakma reputációját is. Harmadik kompetenciakategóriaként a szerződés menedzselésének képessége (3) nevezhető meg. E kompetencia teszi alkalmassá a mentort az elvárások szerződésbe iktatására a megfelelő célképzést sarkallva, valamint a keretek kialakítására, majd a folyamat veze- tése során azok betartására és betartatására. Ezt követően negyedik kategóriaként a kapcsolat kialakításának képességét (4) fogalmaztam meg. Érdekesség, hogy ebben az esetben a megközelítés a hatékony kapcsolat kialakítását, nem pedig a bizalmi viszonyt jelöli meg, mint a korábban bemutatott szakirodalmak (Kahn, 1993; Ragins, 1997; Clutterbuck, 2005; Strachevich, 2009). Ötödik területként a folyamatokba való be- és áttekintést, valamint tanulás képességét (5) neveztem meg, ami magát a folyamatvezetést és annak sajátosságait takarja a modell szerint. Elvárt ugyanakkor az eredmény- és akcióorientált szemlélet (6), amelyek során olyan skillek felvonultatására van szükség, amik támogatják és hozzásegítik a klienst a kívánt változások eléréséhez. Mindennek eléréseként elvárható a mentortól, hogy különböző metódusokat és technikákat alkalmazzon (7) a folyamat során, ezzel is elösegítve a folyamatba történő belelátást és a tanulás facilitálását. 
Végül az értékelési kompetenciát (8) listáztam, amely magában foglalja az adott folyamatra történő visszatekintést, illetve hozzájárul egy több folyamaton átívelő értékelési rendszer és kultúra kialakításához is (http://www. emccouncil.org).

Clutterbuck (2007) legrészletesebb és ezáltal a legdirektívebb modellje figyelembe veszi egyrészt a helyzeti, másrészt a mentorálás időbeli viszonyulását, hangsúlyt helyezve a mentorált szükségletére. Beépíti modelljében továbbá Philipps-Jones (2001) megközelítését is, amely szerint az aktív és figyelmes hallgatás, a bizalomépítés képessége, a célok meghatározása, valamint az ösztönzés és motiválás a mentor legfontosabb tulajdonságai. A leegyszerüsített modellben a mentornak egy képességgel kell rendelkeznie: reagálnia kell tudni a mentorált legkülönbözőbb igényeire (Clutterbuck, 2007, p. 44.). A modell a folyamatot öt - összhang kialakítása, irány kijelölése, haladás, befejezés, informális folytatás - fázisra osztotta (Clutterbuck, 2005).

Az első fázis a kapcsolat kialakításának fázisa, ahol eldől, a mentor és a mentorált akar-e, és leginkább tud-e együtt dolgozni. Ha a kémia nincs meg, vagy az alapvető azonosságok nem adottak, vagy a tapasztalatok közötti különbségekben nem figyelhető meg eltérés - azaz nem adott a lehetőség a tanulásra - akkor a folyamat nem lehet sikeres, eredményes. A fázis legfontosabb kompetenciái az aktív hallgatás, az együttérzés, a pozitív elfogadás tanúsítása, a nyitottság, valamint a bizalom. A második szakasz az iránykijelölés fázisa, amikor a célok meghatározása történik. Ehhez elengedhetetlen a mentor az irányú kompetenciája, hogy képes legyen a cél meghatározására, illetve meghatároztatására, pontosítás és irányítás segítségével, rendelkezzen projektszemlélettel és képes legyen növelni a mentorált elkötelezettségét a konkrét célok irányába, azaz buzdítsa, motiválja és inspirálja. A harmadik szakasz a haladás vagy elöremenetel fázisa, a mentorálási folyamat legfontosabb és egyben idő- és energiafelhasználás szempontjából a legmegterhelőbb szakasza. A mentor, miután segítette a mentoráltat személyes változásának definiálásában és végrehajtásában, támogató és irányító magatartást tanúsít az előrehaladás érdekében makro- és mikrokompetenciák segítségével. Makrokompetenciának tekinthető a mentor azon képessége, hogy tud reagálni a mentorált különböző igényeire, felismeri és egyezteti az esetlegesen egymásnak ellentmondó célokat, beazonosítja, hogy a mentorált a fejlődés és a folyamat mely szakaszában jár és ehhez milyen fokú direktivitás szükséges, valamint rugalmasan alkalmazkodik a szükséges fejlesztési szerepekhez, miközben pozitív, dinamikus légkört biztosít és megtartja az ilyen folyamatoktól elvárt határokat. A mikrokompetenciák közé sorolható a mentornak az összhang megteremtésére való képessége, azaz az aktív hallgatás kompetenciája, az empátia, a nyitottság és a bizalmi légkör kialakítására való törekvés, valamint a kellő motiváló és inspiráló személyiség, valamint olyan, személyes tulajdonságok és attitüdök, mint a kellő önismeret, üzleti/ szakmai hozzáértés, hatékony kommunikáció, konceptuális modellezés, elkötelezettség, kapcsolat- és változásmenedzsment (Clutterbuck, 2005).

\section{Adatgyűjtés és mintavétel}

Jelen cikk egy vegyes módszertanú kutatás kvantitatív, kérdőíves felmérésének részeredményeit mutatja be, amely során célom logikus és tartós összefüggések megállapításán keresztül, bizonyos jelenségek szabályszerüségeinek feltárása volt azzal a céllal, hogy beazonosítsam azon tényezőkombinációkat, amelyek a mentorálásra jellemző, szituációfüggő környezetben, az eltérő célrendszerek és személyiségek figyelembevételével hozzájárulhatnak egy sikeres vállalkozásfejlesztési mentorálási folyamat vezetéséhez.

A vegyes módszertanú - kvalitatív és kvantitatív megkérdezést egyaránt magába foglaló - kutatás során olyan szakembereket, mentorokat, valamint mentorálásában már részt vett vállalkozókat szólítottam meg, akik induló és/vagy fejlődő vállalkozásokban voltak érintettek és jellemzően nagyvállalati belső mentorálási folyamatokon kívül estek. A kutatás során ugyanakkor nem került kikötésre, hogy a folyamatok vizsgálata csak és kizárólag a startup-ok kategóriájába sorolható vállalkozásoknak szóló programokra terjed ki. Ennek oka, hogy a mentorálási folyamatban részt vevő vállalatokra igaz Ries definíciójának első része, miszerint a startup olyan vállalkozás, amelynek célja új termék vagy szolgáltatás létrehozása (Ries, 2011, p. 34.), azonban a definíció második részében kiemeltek, miszerint szélsőségesen bizonytalan feltételek között müködő vállalkozásról van szó, nem feltétlen igaz valamennyi gazdálkodó tevékenységet végző és mentorálásában érintett vállalkozásra. A startupokkal szemben támasztott további követelmények - mint a nagy növekedési potenciál, innováció vezérelt megközelítés, nemzetközi piacra lépés - elvárásként a kutatásba történő beemelése jelentősen csökkentette volna a vizsgálható minta elemszámát.

A tanácsadás elméleti megközelítéseit alapul véve, analógiaként kialakítottam egy hármas tipologizálást a vállalkozásfejlesztési mentorálási tevékenységre nézve, megkülönböztetve az ötlet-, a folyamat- és az ágazati mentort. Ötletmentornak tekintem azt, akit abban az esetben keresnek fel a mentoráltak, amikor körvonalazódik egy ötletük, egy üzleti megoldás vagy innovációs lehetőség, és akinek a segítségét addig veszik igénybe, míg az ötlet piacra nem vihető, feltételezve, hogy az együtt dolgozni kívánó csapat már összeállt, annak összeállítása nem, csoportdinamikájának kezelése azonban a mentor kompetenciája. Ezt követően, vagy már piacképes termék megléte esetén igénybe vehető a folyamatmentor, mint vállalkozásfejlesztési segítő, akinek feladata a vállalkozásindítási és növekedéssel kapcsolatos mindennapi feladatok elősegítése, a gördülékeny ügyvitel biztosítása, de elsősorban a mentorált azon kompetenciáinak fejlesztése és olyan best/ bad practice-k ismertetése, amelyek hozzájárulhatnak a hosszú távú sikeres múködéshez. Az ágazati mentorok pedig azok, akik bizonyos, speciális szaktudást igénylö elakadások esetén állnak a mentoráltak rendelkezésére. Mivel a vonatkozó szakirodalom nem tett egyértelmű utalást arra vonatkozóan, valóban megfigyelhetők-e különböző típusok és ebből adódóan az egyes típusok közötti 
müködésbeli különbségek, érdekes kérdés lehet a későbbiekben annak vizsgálata is, hogy ezen megkülönböztetés helytálló-e, és amennyiben igen, akkor megfigyelhetők-e sajátosságok az egyes típusok esetén.

A szakirodalom áttekintése körvonalazta azon tényezők (kompetenciák, tulajdonságok, attitüdök) listáját, amelyet elemzésre alkalmasnak találtam. A listát próba lekérdezés keretében, a jelentéstartalmak egyértelmüvé tételét követően véglegesítettem, a kérdőíves megkérdezés során így befolyásoló 20 tényezőt vizsgálva. A kutatásba bevont változók ugyanakkor a vállalkozásfejlesztési mentorálás egyes metszeteit vizsgálják, nem térnek ki olyan területekre, mint a munkahelyi befolyás, személyes-családi kötelékek és ezek befolyásolása, számokban mérhető kemény mutatók, mint mentorálási folyamatban való részvétel, diplomák és végzettségek száma stb. A bevont változók esetében célom az volt, hogy kezelhető számú, de a folyamatot még mindig megbízhatóan leíró, érvényes változókat vizsgáljak, mintsem, hogy elaprózott változók miatt torzuljon a minta. A változókat egytől ötig terjedő Likert-skálán mértem, ahol a fontosság esetén a skála végpontjai „egyáltalán nem fontos” (1), és „,abszolút fontos” (5) választ jelentettek, míg a megvalósulás esetén „,egyáltalán nem valósult meg” (1), illetve ,teljes mértékben megvalósult" (5) eseteket írták le.

$\mathrm{Az}$ adatfelvétel sztenderd kérdőív segítségével, online történt, amely összesen 51 kérdést tartalmazott, amelyből 48 megválaszolása volt kötelező. Ezek közül hét a demográfiai adatokra kérdezett rá, további három esetben nyílt kérdés került alkalmazásra, de nem volt kötelező a válaszadás. A kérdőív gerincét egy nyitott és 40 zárt kérdés alkotta: a nyitott kérdés a mentoráltakra és az ő felkészültségükre, attitűdjükre, kompetenciáira vonatkozott. A zárt kérdések a mentorra és magára a folyamatra, oly módon, hogy ugyanazon 20 tényezőt kellett megítélni az egytől ötig terjedő Likertskála segítségével, két dimenzióban: a folyamat során elvárt, azaz kívánatos érték megadásával (1), amelyet a kutatás során a tényező 'fontosságának' neveztem el, valamint visszatekintve arra a (legutolsó) folyamatra, amiben részt vett a megkérdezett, meg kellett határozni a tapasztalatokra vonatkozó értéket az adott tényezők esetén (2), amelyre, mint a 'megfelelés' tényezőjére tekintettem. Ezen elgondolást Parasurman - Zeithaml - Berry által összeállított szolgáltatásminőség-modell alapján építettem fel, amely szerint a szolgáltatások sajátosságaiból, jellemzőiből adódóan öt olyan 'rés' (azaz gap) jelölhető meg, amelyek a szolgáltatás sikertelenséget okozzák (Heidrich, 2006, p. 96.), azaz befolyásolják, vagy befolyásolhatják a vállalkozásfejlesztési mentorálási folyamat sikerességét.

A kérdőívre 158 válasz érkezett, ebböl 153 került a mintába. A minta összeállításakor - az adatok előkészítése során - kiszürtem azokat a válaszokat, amelyek torzították volna az eredményt: minden skálán mérhető kérdésre ugyanazt a választ jelölte meg a válaszadó (1), kötelező nyitott kérdésekre random karaktersorral válaszolt (2), vagy megjegyzésben jelezte, hogy nagyvállalati mentorálási folyamatban vett részt (3). (2. táblázat)

Figyelembe véve a hazai és nemzetközi szakirodalmat, a mintával szembeni elvárásként azt tűztem ki, hogy a férfiak és nők, valamint a mentoráltak és mentorok aránya is körülbelül a 2/3 - 1/3 eloszlást kövesse, mivel szakirodalom feldolgozása során ezen eloszlásra vonatkozó utalások voltak megtalálhatók. A szakirodalom, valamint a vegyes módszertanú kutatás során készített, jelen cikkben bemutatásra kerülő kvantitatív megkérdezést kiegészítő interjúk alanyai - szám szerint kilenc, vállalkozásfejlesztési mentorálási folyamatban aktívan részt vevő mentor, mentorált vagy mentorálási programot támogató, többszörös mentorálási tapasztalattal rendelkező személy - is utaltak rá, hogy a mentori szerepben kifejezetten erős, de a mentoráltak között is jelentős, férfi dominancia figyelhető meg, amely jelenséget a kérdőív kitöltőinek száma utólagosan szintén igazolták. Várható eredmény volt, hogy a válaszadó mentoráltak számossága magasabb lesz, mint a mentoroké. Ez azon egyszerü összefüggéssel magyarázható, hogy mentorálási folyamatban többen vesznek részt, mint ahányan mentorként vállalkozásfejlesztési mentorálási szolgáltatást nyújtanak. Ebből kifolyólag a mintával

A kérdőíves megkérdezés mintaösszetétele

\begin{tabular}{|c|c|c|c|c|c|}
\hline \multirow{2}{*}{\multicolumn{3}{|c|}{ Minta összetétele }} & \multicolumn{2}{|c|}{ Szerep } & \multirow{3}{*}{$\begin{array}{c}\text { Összesen } \\
94\end{array}$} \\
\hline & & & \multirow{2}{*}{$\begin{array}{c}\text { Mentor } \\
40\end{array}$} & \multirow{2}{*}{$\begin{array}{c}\text { Mentorált } \\
54\end{array}$} & \\
\hline \multirow{8}{*}{ Nem } & \multirow{4}{*}{ férfi } & fö & & & \\
\hline & & nemen belül \%-os megoszlás & $42,6 \%$ & $57,4 \%$ & $100,00 \%$ \\
\hline & & szerepen belül \%-os megoszlás & $67,8 \%$ & $57,4 \%$ & $61,4 \%$ \\
\hline & & teljes mintán belül \%-os megoszlás & $26,1 \%$ & $35,3 \%$ & $61,4 \%$ \\
\hline & \multirow{4}{*}{ nö } & fö & 19 & 40 & 59 \\
\hline & & nemen belül \%-os megoszlás & $32,2 \%$ & $67,8 \%$ & $100,00 \%$ \\
\hline & & szerepen belül \%-os megoszlás & $32,3 \%$ & $42,6 \%$ & $38,6 \%$ \\
\hline & & teljes mintán belül \%-os megoszlás & $12,4 \%$ & $26,1 \%$ & $38,6 \%$ \\
\hline \multirow{4}{*}{\multicolumn{2}{|c|}{$\begin{array}{c}\text { Összesen } \\
\text { nemen belül \%-os megoszlás } \\
\text { szerepen belül \%-os megoszlás } \\
\text { teljes mintán belül \%-os megoszlás }\end{array}$}} & fö & 59 & 94 & 153 \\
\hline & & $38,6 \%$ & $61,4 \%$ & $100,00 \%$ & \\
\hline & & $100 \%$ & $100,00 \%$ & $100,00 \%$ & \\
\hline & & $38,6 \%$ & $61,4 \%$ & $100,00 \%$ & \\
\hline
\end{tabular}


szemben elvárásként fogalmazódott meg az is, hogy életkor szempontjából közel egyenletes eloszlású legyen.

Mivel az alapsokaságról nem álltak rendelkezésre ismeretek, továbbá nem elérhető vállalkozásfejlesztési mentorálási folyamatban részt vettekről adatbázis, az alapsokaság nem megfelelő ismerete nem tette lehetővé a valószínüségi mintavétel lefolytatását, így a kvantitatív kutatás során az előzőekben említett hólabdatechnikát alkalmaztam. A megkérdezés során az alanyok elsődleges megszólítása a szerző által felépített adatbázis segítségével történt, majd innen tovább lépve és többnyire ismertség alapján történt az eljutás a válaszadó alanyokhoz. Ezért a minta nem tekinthetö reprezentatívnak, azonban feltáró kutatásról lévén szó, a téma megismerésére való tekintettel e technika elfogadott a megkérdezés lebonyolítására. A nem reprezentatív minta kialakításakor azon törekvés megfigyelhető a kérdőíves felmérés során, hogy a számosság növelésével egy becsületes eljárás keretében olyan mintanagyságot vonjak be a megkérdezettek körébe, amely biztosítja a különbözőséget az egyes megkérdezettek között, megengedi továbbá a többváltozós statisztikai elemzések elvégzését is, de nem túlzottan hígítja a mintát, azaz nem emel be olyan válaszadókat, akik nem relevánsak a vizsgált kérdéskörben.

Az egyes változópárok közötti összefüggést a Cramerféle $\mathrm{V}$ mutató segítségével vizsgáltam: erős kapcsolat figyelhető meg a születési idő (életkor) és a betöltött szerep (mentor/mentorált) változók között (Cramer-féle V mutató értéke $0,732, p=0,000$ ), közepes erösségü a kapcsolat a legmagasabb iskolai végzettség és a szerep (Cramer-féle $\mathrm{V}$ mutató értéke $0,498, \mathrm{p}=0,000$ ), illetve a foglalkozás és a betöltött szerep (Cramer-féle $\mathrm{V}$ mutató értéke 0,640, $\mathrm{p}=0,000)$ között, míg nem figyelhető meg kapcsolat a szerep és a lakhely (Cramer-féle $\mathrm{V}$ mutató értéke 0,188 , $\mathrm{p}=0,143$ ), valamint a nem és a szerep között (Cramer-féle $V$ mutató értéke $0,103, p=0,200$ ). Az elemzések megkezdése előtt és a kutatás során használt adatfelvétel megbízhatóságának ellenőrzése érdekében Cronbach-alfa elemzést is végeztem, amely mind fontosság, mind megfelelés esetén, valamennyi mutatóra nézve elérte a kívánatos 0,7 -es értéket.

\section{Faktorelemzés és a modell felállítása}

Mint számtalan egyéb társadalomtudományi kutatás során, jelen kérdőíves felmérés esetében is - kiegészítve a dolgozat egyik célját képező, áttekinthető és könnyen alkalmazható modell megalkotásának szükségességével - felmerül az igény a változók számának redukálására a könnyebb értelmezhetőség érdekében, mégpedig információveszteség nélkül. E célból faktorelemzést végeztem, amely segítségével a nagyszámú változók számának csökkentésére, adattömörítésre és az adatstruktúra feltárására tettem kísérletet, annak céljából, hogy a változók közötti multikollineralitást kiszürjük (Sajtos - Mitev, 2007, p. 245.). A modell megalkotásához a faktorelemzés azért is tud hozzájárulni, mert az nem struktúra-ellenőrző, hanem struktúrafeltáró módszer, ami azt jelenti, hogy nincsenek elöre meghatározott függő és független változók, hiszen az elemzés a változók közötti összefüggések feltárására törekszik, valamint az így kapott faktorváltozók megkönnyíthetik a további - pl. klaszter - elemzéseket is (Sajtos - Mitev, 2007, p. 247). A modell felállításán túl, két hipotézist vizsgáltam.

A szakirodalom alapvető és kiindulási állapotnak tekinti, hogy a mentor és mentorált között van életkorbeli különbség, azaz tapasztalatbeli eltérés. Ez egyrészt iparági tapasztalatok terén, másrészt szakmai tudásbeli - széles körü gazdasági és üzleti ismeretek - különbségként jelenik meg. A H1 hipotézis azt vizsgálja, hogy az iparági tapasztalatnak és az üzleti ismereteknek egymás kiegészítőjeként szükséges-e megjelennie a vállalkozásfejlesztési mentorálási folyamatban. A szakmai tudás és iparági tapasztalat mellett leggyakrabban kiemelt sikerkritérium a vállalkozásfejlesztési mentorálási folyamatban a bizalmi légkör megléte, illetve annak kialakítására való törekvés (pl. Kram, 1985; Kahn, 1993; Ragins, 1997; Clutterbuck - Lane, 2005; Starchevich, 2009; Dávid, 2014). E légkör megteremtése azért is döntő fontosságú, mert a mentor és mentorált összetett kapcsolatrendszerében a közöttük fennálló szoros együttműködésre és a folyamat során megosztott információkra, praktikákra és taktikákra, az emberi kapcsolódás, a bizalmon túlmenően mutatott kölcsönös egymásra hangolódás csak akkor jöhet létre, ha a folyamatban jelen van az empátia, a nyitottság és pozitív attitüd, amelyhez hozzájárul a mentor hitelessége is. A H2 hipotézis keretében azt vizsgálom, hogy a vállalkozásfejlesztési mentorálási folyamat működhet-e egy olyan tényezőkombináció nélkül, amely az empátia, a kölcsönös bizalom, a hitelesség, a pozitív attitüd és a nyitottság tényezöit tartalmazza.

A faktorelemzés elvégzése előtt vizsgálatot végeztem annak érdekében, hogy az adatbázisban szereplő adatok eleget tesznek-e a faktorelemzés követelményeinek, így meghatároztam a Kaiser-Meyer-Olkin (KMO) mutatót, valamint elvégeztem a Bartlett-féle szférikus tesztet is. Mindkét teszt a főkomponens-elemzés alkalmazhatóságát bizonyította: a KMO értéke 0,535 - amely meghaladja a mutatótól elvárt minimális 0,5 -ös értéket (Füstös, 2007) - azaz közepes illeszkedést mutat, míg a Bartlett-teszt szignifikanciaszintje $0,000 \quad(\chi 2=405,537$, szabadságfok $(\mathrm{df})=171)$, amely szintén alátámasztja a változók korrelálatlanságát, így a változókat faktorelemzésre alkalmasnak ítéltem. A faktorok számának meghatározása során két dolgot vettem figyelembe: egyrészt áttekintettem, hogy az SPSS által elóállított Scree Plot-ábra, amely a sajátértékeket ábrázolja a faktorok sorrendjében - hányas faktorstruktúrát javasol, másrészt figyelembe vettem azt a legegyszerübb szabályt (Kaiser-kritérium), hogy annyi faktor képezhető egy változóhalmazból, ahány esetben a fökomponens saját értéke meghaladja az egyet (3. táblázat). Továbbá teszteltem varianciahányad-módszerrel is a faktorok számát, amely szerint a társadalomtudományokban elfogadott hüvelykujj szabály szerinti, $60 \%$ os kritériumszint eléréséhez köthető a faktorok száma. Végső faktorstruktúrának ezen eredményeket figyelembe véve, a hatfaktoros megoldást választottam. Amennyiben ugyanis megvizsgáljuk az egyes faktorok tartalmát, akkor 
Magyarázott varianciatáblázat

\begin{tabular}{|c|c|c|c|c|c|c|c|c|c|}
\hline \multicolumn{10}{|c|}{ Total Variance Explained } \\
\hline \multirow{2}{*}{$\begin{array}{c}\text { Com- } \\
\text { ponent }\end{array}$} & \multicolumn{3}{|c|}{ Initial Eigenvalues } & \multicolumn{3}{|c|}{ Extraction Sums of Squared Loadings } & \multicolumn{3}{|c|}{ Rotation Sums of Squared Loadings } \\
\hline & Total & $\begin{array}{c}\% \text { of } \\
\text { Variance }\end{array}$ & $\begin{array}{c}\text { Cumulative } \\
\%\end{array}$ & Total & $\begin{array}{c}\% \text { of } \\
\text { Variance }\end{array}$ & Cumulative \% & Total & $\begin{array}{c}\% \text { of } \\
\text { Variance }\end{array}$ & Cumulative \% \\
\hline 1 & 3,325 & 20,783 & 20,783 & 3,325 & 20,783 & 20,783 & 1,922 & 12,011 & 12,011 \\
\hline 2 & 1,641 & 10,256 & 31,039 & 1,641 & 10,256 & 31,039 & 1,842 & 11,512 & 23,523 \\
\hline 3 & 1,434 & 8,964 & 40,004 & 1,434 & 8,964 & 40,004 & 1,816 & 11,347 & 34,87 \\
\hline 4 & 1,211 & 7,568 & 47,572 & 1,211 & 7,568 & 47,572 & 1,504 & 9,402 & 44,272 \\
\hline 5 & 1,136 & 7,102 & 54,674 & 1,136 & 7,102 & 54,674 & 1,445 & 9,031 & 53,303 \\
\hline 6 & 1,068 & 6,674 & 61,347 & 1,068 & 6,674 & 61,347 & 1,287 & 8,044 & 61,347 \\
\hline 7 & 0,9 & 5,623 & 66,97 & & & & & & \\
\hline 8 & 0,805 & 5,029 & 71,999 & & & & & & \\
\hline 9 & 0,766 & 4,79 & 76,789 & & & & & & \\
\hline 10 & 0,751 & 4,694 & 81,483 & & & & & & \\
\hline 11 & 0,617 & 3,857 & 85,34 & & & & & & \\
\hline 12 & 0,569 & 3,556 & 88,896 & & & & & & \\
\hline 13 & 0,541 & 3,383 & 92,279 & & & & & & \\
\hline 14 & 0,481 & 3,003 & 95,283 & & & & & & \\
\hline 15 & 0,442 & 2,763 & 98,045 & & & & & & \\
\hline 16 & 0,313 & 1,955 & 100 & & & & & & \\
\hline
\end{tabular}

Extraction Method: Principal Component Analysis

arra a megállapításra juthatunk, hogy jól definiálható kapcsolat figyelhető meg az egyes faktorokat alkotó változók között, így lehetőség nyílik a folyamattal szembeni elvárások csoportosítására, azaz egy könnyen átlátható modell vagy ellenőrzőlista implementálására.

A faktorelemzés elkészítése során több változatot is elemeztem. Ennek okaként az nevezhető meg, hogy egyrészt a vizsgálat tárgya lehet a tényezők fontossága, másrészt pedig megvalósulása is (1), ugyanakkor a vállalkozásfejlesztési mentorálási folyamat, hasonlóan más szolgáltatásokhoz, erősen fogyasztóorientált (2), így érdekes eredményekhez vezethet, ha vizsgálom a keresleti oldal sajátosságait is, nemcsak a teljes mintát. Kiindulópontnak ennek ellenére azt a faktorelemzést tekintem, amely a tényezők fontosságát veszi alapul teljes mintán, mivel ez reprezentálja a folyamattal szembeni elvárásokat, nem pedig a megvalósult szolgáltatás minősége, ugyanakkor magában foglalja mind a mentorok, mind a mentoráltak, tehát a folyamat résztvevőinek mindkét csoportját és azok folyamattal kapcsolatos elvárásait is. Ennek az elemzésnek a futtatása során az optimális modellben négy tényező - benchmarking- és viszonyítási képesség, empátia, integritás és projektorientált szemléletvezetés - elhagyására kényszerültem, mivel e tényezők esetén gondot okozott a faktorokhoz való illesztés, ugyanis egyik esetben sem volt megfigyelhető, hogy bármely más tényezővel hasonlóan viselkednének, ugyanakkor nem tekinthetők önálló faktornak sem, mivel abban az esetben önálló tényezőként, nagy súllyal, megfelelő kommunalitási értékkel a faktorelemzésben kellett volna maradnia e tényezőknek.

A faktorok tartalmának összehasonlításához a Varimax-módszerrel rotált faktorsúly mátrixot alkalmaztam, így biztosítva a faktorok korrelálatlanságát, 61,533\%-os teljes magyarázott variancia értékkel (4. táblázat).

A faktorstruktúra alapján az empátia, valamint a benchmarking képesség tényezője nem került a faktorba, amelynek két oka lehet: vagy önálló faktorként viselkednek (1), vagy nem volt megfigyelhető illeszkedés más tényezőkhöz (2). Felmerülhet kérdésként, mi a magyarázata a tényezők modellből történő kimaradásának. Az elemzések nem támasztották alá, hogy önálló faktorként viselkednek a kimaradt tényezők, így azokra, mint a folyamat természetes velejárójára tekintettem. Ez azzal is magyarázható, hogy a mentorálási folyamat természetes velejárója a viszonyítási pontok és ismeretek megosztása, miközben jó, és rossz gyakorlatokat ismertet (benchmarking), mindezt úgy teszi, hogy önmaga teljes valójában, tapasztalataival, ismereteivel, tudásával és véleményével van jelen a folyamatban (integritás), miközben megfelel a projektorientált szemlélettől elvártaknak, azaz meghatározott időre és célból, a rendelkezésre álló erőforrásokat figyelembe véve szerződik egy folyamatra, amely során 
Teljes mintán alapuló rotált faktorsúly mátrix

\begin{tabular}{|c|c|c|c|c|c|c|c|c|}
\hline \multirow{2}{*}{ Faktor elnevezése } & \multirow{2}{*}{$\begin{array}{l}\text { Faktor } \\
\text { száma }\end{array}$} & \multirow{2}{*}{$\begin{array}{c}\text { Rotated component } \\
\text { matrix }\end{array}$} & \multicolumn{6}{|c|}{ Component } \\
\hline & & & 1 & 2 & 3 & 4 & 5 & 6 \\
\hline \multirow{4}{*}{ Mentor hitelessége } & \multirow{4}{*}{ Faktor_1 } & Belső kommunikáció & 0,746 & & & & & \\
\hline & & Hitelesség & 0,697 & & & & & \\
\hline & & Hard keretek & 0,593 & & & & & \\
\hline & & integritás & 0,463 & & & & & \\
\hline \multirow{3}{*}{$\begin{array}{l}\text { Mentorált felé irányuló } \\
\text { kommunikációs kompetencia }\end{array}$} & \multirow{3}{*}{ Faktor_2 } & Tükörtartás & & 0,705 & & & & \\
\hline & & Aktív hallgatás & & 0,705 & & & & \\
\hline & & Kommunikáció kifelé & & 0,644 & & & & \\
\hline \multirow{3}{*}{$\begin{array}{l}\text { Bizalom megteremtésének } \\
\text { képessége }\end{array}$} & \multirow{3}{*}{ Faktor_3 } & Szimpátia & & & 0,699 & & & \\
\hline & & $\begin{array}{l}\text { Bizalmi légkör kiala- } \\
\text { kítása }\end{array}$ & & & 0,698 & & & \\
\hline & & Holisztikus szemlélet & & & 0,636 & & & \\
\hline \multirow{3}{*}{$\begin{array}{l}\text { Változás támogatásának } \\
\text { képessége }\end{array}$} & \multirow{3}{*}{ Faktor_4 } & Pozitív attitüd & & & & 0,699 & & \\
\hline & & Változás menedzselése & & & & 0,616 & & \\
\hline & & Nyitottság & & & & 0,557 & & \\
\hline \multirow{2}{*}{ Hard skillek } & \multirow{2}{*}{ Faktor_5 } & Gazdasági ismeretek & & & & & 0,787 & \\
\hline & & Iparági tapasztalat & & & & & 0,668 & \\
\hline \multirow{3}{*}{ Holisztikus látásmód } & \multirow{3}{*}{ Faktor_6 } & Célorientált szemlélet & & & & & & 0,713 \\
\hline & & $\begin{array}{c}\text { Projektorientált szem- } \\
\text { lélet }\end{array}$ & & & & & & 0,592 \\
\hline & & $\begin{array}{c}\text { Folyamatorientált szem- } \\
\text { lélet }\end{array}$ & & & & & & 0,580 \\
\hline
\end{tabular}

Extraction Method: Principal Component Analysis; Rotation Method: Varimax with Kaiser Nomination; Rotation converged in 7 iterations. N=153

Forrás: saját szerkesztés

figyel az egyensúly szigorú fenntartására, azaz a profeszszionális viszony és a baráti kapcsolat határ mezején való mozgásra, tehát nem lesz sem túl empatikus, sem távolságtartó.

\section{Következtetés - A sikeres folyamatvezetéshez szükséges mentori kompetencia, tulajdonság és attitüdlista hattényezős modellje}

A faktorelemzés rámutatott arra, hogy felállítható egy olyan, hat tényezőcsoportra osztható modell, amely azonosítja a sikeres vállalkozásfejlesztési mentorálási folyamathoz elengedhetetlen, a mentor által birtokolni szükséges tulajdonságokat, kompetenciákat és attitüdöket. A kutatásnak ugyanakkor nem volt célja egy, valamennyi mentorálási folyamatban receptként használható eszköz kialakítása, sokkal inkább szem elött tartotta a faktorelemzés struktúrafeltáró voltát - mintsem annak struktúraelemző szemléletét - hiszen nem voltak előre meghatározott függő és független változók, az elemzés pedig az egyes változók közötti összefüggések feltárására törekedett. A faktorelemzés eredményeképpen kialakított modellre, mint checklist-re, ellenörző listára lehet tekinteni, ami irányt mutat a sikeres folyamatvezetéshez, eszköznek azonban nem tekinthető, hiszen nem szabályozza a folyamatot lépésről lépésre, csupán a neuralgikus pontokra hívja fel a figyelmet. Ennek eredményeképpen, a sarokpontok figyelembevételével a mentor szituáció függően, az iránymutató keretek között tudja folyamatra szabni mentorálási tevékenységét.

\section{A 'mentorált megértésének képessége' faktor}

Az első faktorba került az aktív hallgatás, a tükörtartás és mentor mentorált felé irányuló kommunikációs kompetenciáinak összessége. A faktor a 'Mentorált megértésének képessége' nevet kapta, mivel azokat a soft-skilleket foglalja magában, amelyek a folyamat során a mentor mentorált felé irányuló kommunikációját jellemzik, azaz amik segítségével meg kívánja érteni a mentoráltat: kérdez, figyel, reflektál, visszajelez, megerősít és magyaráz. A mentorálási folyamat esetén a legalapvetőbb eszköz a kérdezéstechnika, annak megfelelő használata, valamint kombinálása más eszközökkel. A kérdezéstechnika két legalapvetőbb eszköze a zárt és nyitott kérdések alkalmazása: a zárt kérdések ellenőrzésre, nyomatékosításra, visszakérdezés céljából alkalmazhatók, túl magas számosságuk azonban korlátozza a mentorált szabadságát, és irányítja gondolatmenetét. Éppen ezért a megismerési folyamatban az egyensúlyra való törekvés a kívánatos, ahol a nyílt kérdések használatával a mentorált megnyílhat, terelheti a mondandót, irányíthatja az ülést, pontosíthat, kiterjesztheti, vagy éppen szükítheti a témát. A mentorált felé irányuló kommunikáció formája lehet a hipotézisek 
és állítások alkalmazása is, amely azért előnyös, mert oly módon vezeti a mentorált gondolkodását, hogy közben beleszövi a mentor saját álláspontját, véleményét is.

A mentor kompetenciái között kell, hogy szerepeljen a hallottak visszamondása és annak képessége, egyfajta szintetizáció, a hallottakra történő reagálás, az ügyfél felé fordulás és szemkontaktus tartása, a nyílt és félre nem érthető testbeszéd. A faktor tartalma nagyfokú hasonlóságot mutat Covey (2004) elméletének ötödik szokásával, a kölcsönösség elvével. Sikeresen ugyanis csak akkor tudunk müködni, ha előbb megértjük a másik felet (ez a vevőorientált szemlélet a marketingben), majd ezt követően értetjük meg mi magunkat vele, ami nem más, mint a benchmarking gyakorlata a mentorálásban. A hagyományos iskolarendszer elsősorban az írás és az olvasás képességére helyezi a hangsúlyt, de az aktív kommunikáció nem lehet sikeres, ha azt nem előzi meg hallgatás. A kommunikáció irodalma erre a tevékenységre, mint az aktív hallgatásra hivatkozik, amely nem más, mint az empatikus odafigyelés. Ennek lényege, hogy elsősorban nem megértetni akarjuk magunkat a másikkal, tehát nem azért hallgatjuk meg, hogy aztán válaszolhassunk, azaz nem a saját nézőpontunkból vetítjük le az adott filmet, hanem azzal a céllal, hogy figyelembe vehessük a másik álláspontját, megérthessük helyzetét. Sokaknál ez gondos odafigyelést és paradigmaváltást igényel, mivel úgy vélekednek - és ez bizonyos szempontból igaz is - megfelelően és teljes egészében látják az adott kérdést, meg vannak győződve saját igazukról, miközben számos más, akár a teljes szituációt nagymértékben befolyásoló egyéb nézőpont áll rendelkezésre. A hibát az aktívan hallgatni nem tudó vezetők ott követik el, hogy saját igazukra koncentrálnak, ignorálják más álláspontját, egyfajta entocentrikus szemléletet figyelembe véve elégedettek saját álláspontjuk helyességével (Zsigmond - Tasi, 2016).

\section{A 'folyamatvezetési kritériumok kialakításának képessége' faktor}

A faktorelemzés eredményeképpen a mentor 'belső' kommunikációját, a hard keretek kialakításának képességét, valamint a hitelességet tekinthetjük a második faktornak. Belső kommunikáció alatt azt a szabályrendszert értjük, ahogyan a mentor és a mentorált kapcsolatot tart egymással: szabályozza a találkozások közötti időben történő kommunikációs lehetőséget, annak módját, csatornáját és gyakoriságát. Ez nagymértékben kötődik a hard keretek meglétéhez, amely egy megállapodás - azaz szerződés kialakításának kompetenciáit jelöli. Ennek során történik meg a felek közötti szerződés: a célok megfogalmazása, az ülések hosszának és gyakoriságának meghatározása, a találkozók helyének egyeztetése, a lemondás és a folyamat abbahagyásának feltételei, az etikai aspektusok beemelése, a fö irányok kijelölése, valamint a szerepek, feladatok és felelösségi körök meghatározása. Összefoglalóan ezt a szakirodalom a szerződéskötés folyamatának tekinti, amely három pilléren nyugszik, és ami lehet szóbeli meg- állapodás, vagy írott szerződés. Ezek szerint megkülönbözteti a keretfeltételek meghatározását (1), mint a találkozók helyszíne, az időpontok és gyakoriság, a várható folyamathossz, az együttmüködés céljainak lefektetését (2) - ki mit vár a folyamattól, illetve mi a folyamatban az egyes szereplök szerepe és feladata, valamint az információk kezelésével kapcsolatos megállapodás szükségességét (3) - mind dokumentáció, esetleges riportálás és bizalmi kérdések tisztázása - mind a hatékony müködés, az etikai és egyéb folyamatvezetési problémák elkerülését szolgálják. Keretek kialakítása alatt értjük továbbá a mentorálási kapcsolat strukturálását, ezen belül a célok, projektek és aktivitások meghatározását (Belcourt et al., 2000), a kapcsolat időtartamára és az egyes találkozások időkeretének meghatározására vonatkozó megállapodást (Waters, 2002), ehhez kapcsolódóan az ülések gyakoriságát, valamint a kapcsolattartás mikéntjét (Smallbone et al., 1998; Lankau et al., 2005; Cull, 2006) is. A folyamat sikerességéhez e tényezők meghatározása erőteljesen hozzájárul, de nem jelenti azt, hogy biztosan sikeres is lesz az, hiszen a szakmai tartalom, az ülések milyensége, a résztvevők attitűdje, a mentor felkészültsége, ismeretei és tapasztalata fontos, befolyásoló szereppel fognak bírni (St. Jean - Audet, 2009).

A mentor és a mentorált közötti kapcsolat kialakításának döntő fontosságú pontja, a kereteken túlmutatóan, megfelelő együttmüködési légkör megléte és kialakítása, amely két aspektusra bontható: egyrészt figyelmet kell fordítani a mentor hitelességére (1), valamint a bizalom teremtésének (rapport) szempontjára (2) is, amit önálló faktorként vizsgálok a későbbiekben. A folyamat sikerességének szempontjából a hitelesség több szerző szerint is kulcsfontosságú (Hollister - Sutter, 2001; Kunos, 2011; Nagypál, 2016; Palmer, 2016). A hitelesség kérdése ezen értelmezésben nemcsak szakmai, hanem emberi hitelességet is jelent. Ezen a ponton jut jelentőséghez ugyanis az, hogy szakmai felkészültsége és tapasztalata mellett elért-e valamilyen területen valami számottevőt a mentor - legyen szó müvészetről, sportról, tudományról vagy üzletről -, büszke-e teljesítményére, tudatában van-e elért eredményeinek és ebből kifolyólag önzetlenül tudja és akarja-e kamatoztatni megszerzett tudását és tapasztalatát, azaz átadja-e és önzetlenül segíti-e a mentoráltat céljainak elérésében.

\section{A 'bizalom megteremtésének képessége' faktor}

A folyamatot akkor lesz képes vezetni a mentor, ha nemcsak a kommunikáció sajátosságait és a kereteket tisztázzák a felek, hanem kialakul egyfajta elfogadás is. Ennek kialakításában szerepet játszó egyik tényező a mentor hitelessége (ld. második faktor), valamint a bizalom teremtésének képessége, amelyet a segítő foglalkozásokat feldolgozó irodalom raport ${ }^{1}$ teremtéseként aposztrofál. A bizalom kialakításához kapcsolódó tipikus kérdés, hogy tud-e együtt dolgozni a mentor és a mentorált, azaz res- 
pektálják-e egymást. Ehhez kapcsolódóan, harmadik faktorként azonosítottam a szimpátia és a bizalmi légkör kialakításának képességét, amely együttesen a 'Bizalom megteremtésének képessége' faktornevet kapta.

A faktor tartalma egybeesik Garringer (2015) modelljével, aki szerint egy tartós és hatékony mentorálási kapcsolat kialakítása során a mentor és a mentee illeszkedésének biztosítására van szükség, amely nem más, mint a bizalom megteremtése és a kölcsönös szimpátián alapuló, úgynevezett matching megléte. Azonban magában a matching, vagy más néven illeszkedés fogalmának kérdéskörében sem egységes a szakirodalom, hiszem a demográfiai és iparági tapasztalatokon túlmutatóan az attitűdalapú megközelítés biztosítását is fontosnak találják (St. Jean - Audet, 2009). Egyes szerzők ezen illeszkedést nemcsak szakmai és emberi téren, de tanulási stílus esetében is jelentősnek tekintik (Mumford, 1995; Sullivan, 2000; Devins et al., 2005).

A modell esetében a bizalom kialakítására való törekvést, mint a mentor biztató/motiváló magatartását értem, amellyel ösztönzi a mentoráltat helyzetének ismertetésére. Mindennek elösegítése végett olyan eszközöket alkalmaz, mint a humor és az önirónia, amely megnyitja a másik felet, ezzel hozzájárul és elősegíti azt, hogy létre jöjjön a kölcsönös adok-kapok, ezáltal pedig a kölcsönös tanulás légköre. Ehhez szükséges a korábban bemutatott mentori hitelesség tényezőjének megléte is, hiszen azzal kiegészülve képes a mentor üzenetet közvetíteni és visszajelzést adni a mentoráltnak, legyen az akár negatív, akár pozitív.

A faktor másik tényezője a személyes szimpátia meglétét feltételezi, azaz azt vizsgálja, adott-e a közös hang a mentor és mentorált között. A szimpátia és a kémia fogalmát gyakran szinonimaként használják a mentorálási kontextusban. Míg a matching fogalmát szakmai kontextusban fogalmazhatjuk meg, addig a szimpátia és a kémia az ember-ember közötti viszonyt fogja leírni. Mentor és mentorált ugyanis akkor lesz képes sikeresen együtt dolgozni, ha közöttük, mint emberek között, egyfajta hasonlóság figyelhető meg: gondolkodásmódjukban, értékrendszerükben, hozzáállásukban vagy célrendszerükben. Amennyiben ez fennáll, könnyen képesek megbízni a másik félben, gyorsan és zökkenőmentesen tudnak együtt dolgozni, amely mindkettőjüknek pozitív élményt ad, és kapcsolatuk inkább baráti, mintsem szakmai, de mindenesetre átszövi azt a nagyfokú bizalom. A köznyelv erre az állapotra olyan kifejezéseket használ, mint 'egymásra vannak kattanva', vagy 'egy húron pendülnek', esetlegesen 'fél szavakból is megértik egymást'. E kölcsönösség nélkül nehezen, vagy egyáltalán nem alakulhat ki sikeres és eredményes kapcsolat mentor és mentorált között.

A H2 hipotézis keretében, amely szerint 'a vállalkozásfejlesztési mentorálási folyamat nem müködhet egy olyan tényezőkombináció nélkül, amely az empátia, a kölcsönös bizalom, hitelesség, pozitív attitüd és nyitottság tényezőit tartalmazza', elutasítottam, mivel az empátia nem került faktorba - még ha fontosság megítélése alapján viszonylag magas értékeket és előkelö rangsorhelyet kapott - a további tényezőket pedig két faktorba, külön soroltam be, azaz szükségesek a folyamat sikeréhez, de nem tekinthetők egy tényezőkombinációnak.

\section{A 'változás támogatásának képessége' faktor}

A bizalmi légkör kialakításához hozzájárul a negyedik faktor is, amely a 'változás támogatásának képessége' nevet kapta, és amely olyan tényezőket foglal magába, mint a nyitottság, a pozitív attitűd és a változás menedzselésének képessége. Valamennyi segítő tevékenységet folytatótól elvárható, hogy nyitottan és optimistán álljon a folyamathoz (Clutterbuck, 2005; Bencsik, 2012; Memon et al., 2013), azaz a mentor minden rezdülését, visszajelzését az jellemezze, hogy érdekli, ami a mentorálttal történik, azaz nyitott, ő maga is szeretné, ha sikeres lenne az, amivel foglalkoznak a folyamat során, ennek érdekében az ehhez szükséges nézőpontokat, eszközöket és módszereket implementálja a mentorálási folyamat során, valamint ezen túlmutatóan egészséges észleléssel és magas fokú türelemmel (Statchevich, 2009) is rendelkezik. Eme mentortól elvárt általános nyitottság két területen értelmezhető: egyrészt általánosan (1), azaz feltételezi a nyitott szemmel a világban járó és befogadó jellegü hozzáállást, ugyanakkor nyitottságot feltételez a közös együtt gondolkodásra (2) is. Egyfajta önzetlenséget is feltételez a mentor részéröl: megvan az a képessége, hogy tudja és akarja is megszerzett tudását és tapasztalatát átadni, saját ötleteken és véleményen kívül más nézőpontját, tapasztalatait és elakadásait is hajlandó figyelembe venni, megfontolni azokat és dolgozni velük, illetve rajtuk. Tehát képes integráltan, a teljes képre (big picture) fókuszálni.

Mindezt annak érdekében teszi, hogy megvalósuljon a vállalkozásfejlesztési mentorálási folyamat fő célja, a változás előidézése, azaz a status quo állapotából történő elmozdulás. Ehhez szükséges, hogy a mentor jártas legyen a változások világában, ismerje a változások menedzselésének folyamatmodelljeit, tudja kezelni a mentorált kockázatvállalási hajlandóságának mikéntjét, és ehhez képes legyen testreszabni a változás lebonyolítását, hosszabb időtávú gondolkodásra sarkallja a mentoráltat, ugyanakkor technikákat is képes legyen tanítani pártfogoltja számára, hogy az a tényleges és valós helyzettel azonosuljon és tudjon szembenézni, miközben motiválja, bíztatja és a mérföldkövek elérése kapcsán dicséri is a fejlődni, változni vágyót. Ugyanakkor szükséges rendelkeznie bizonyos krízisintervenciós ismeretekkel is.

\section{A 'szakmai ismeretek' faktor}

A kutatás során a legvitatottabb kérdés az adott üzletághoz tartozó ismeretek, illetve az általános gazdasági-üzleti tudás kérdésköre között alakult ki. Abban többnyire egyetértés figyelhető meg, hogy valamiféle hozzáértés megléte szükséges a mentor részéről, mert így elkerülhetők - vagy legalábbis csökkenthetők - a mentorált részéröl elkövethető hibák (Ebrahimi, 2013), de abban már koránt sincs egyetértés, hogy ez a 'hozzáértés' mit takar. 
Tapasztalat terén a meglátások két végletet mutatnak: Deakins és szerzőtársai (1997) szerint, ahhoz, hogy hatékonyan és sikeresen valósuljon meg egy vállalkozásfejlesztési mentorálási folyamat, feltétlenül szükséges, hogy a folyamatban részt vevő felek ugyanazt az iparágat képviseljék, míg Bisk (2002) szerint ennek pontosan az ellenkezője is bebizonyítható. A szélsőségek mellett köztes álláspontokkal is találkozhatunk: Sorcinelli - Yun (2007) átfogó elméleti ismeretek lehetnek egyrészt tanulás (graduális oktatás) útján elsajátítottak, ugyanakkor végzett tevékenység során, gyakorlati úton, azaz learning-bydoing módon szerzettek is. Így a mentor felkészültségét a modellben semmiképpen sem végzettséghez kötném, sokkal inkább azokhoz az ismeretkörökhöz, amelyekkel rendelkeznie kell. E hard ismeretkörök felépítését az 5. táblázat szemlélteti.

A mentor által birtokolni szükséges ismeretek listája

\begin{tabular}{|c|c|c|c|}
\hline Egyéb hard ismeretek & Pénzügy és finanszírozás & Üzleti tervezés és modellezés & Marketing és sales \\
\hline jog & beruházás & értéklánc-menedzsment & marketing \\
\hline müszaki ismeretek & finanszírozás és költségvetés & stratégiai ismeretek & értékesítés \\
\hline $\begin{array}{c}\text { informatikai és info-kommuni- } \\
\text { kációs ismeretek }\end{array}$ & $\begin{array}{c}\text { számviteli és ügyviteli isme- } \\
\text { retek }\end{array}$ & logisztika & \\
\hline $\begin{array}{c}\text { matematikai és statisztikai } \\
\text { ismeretek }\end{array}$ & & emberi eröforrás & $\begin{array}{c}\text { kereslet teremtés } \\
\text { és menedzselés }\end{array}$ \\
\hline
\end{tabular}

szerint mind az elméleti tudásnak, mind pedig a gyakorlati tapasztalatnak valamennyi olyan területen adottnak kell lennie, amelyet a mentorálási tevékenység érinthet. Dickinson és szerzötársai (2009) inkább a folyamat diadikus voltát hangsúlyozzák, amelynek során a bizalmi légkör létrejöttét követően a mentorált megosztja elakadásait, kérdéseit mentorával, aki ezekre reagálva, elméleti szakmai ismereteit vagy ehhez kapcsolódó gyakorlati tapasztalatát, vagy a kettő kombinációját osztja meg vele. Álláspontomhoz inkább utóbbi megközelítés áll közel, mert úgy gondolom, a mentori eszköz- és példarendszerből mindig azokat az elemeket szükséges alkalmazni, amik a legtesthezállóbbak, és helyzethez leginkább megfelelők. Ezek meglétéhez azonban nem feltétlenül szükséges ugyanazon iparágból származó tapasztalat.

A tapasztalatot viszont értelmezhetjük másképpen, mégpedig úgy, hogy az nem más, mint korábbi, lezajlott fejlesztési tevékenységben való részvétel. Ahhoz ugyanis, hogy a mentee elakadását, szükségletét pontosan azonosítani tudja a mentor, feltétlen szükséges, hogy rendelkezzen korábbi, ez irányú, vagy hasonló tapasztalatokkal (Zsigmond - Tasi, 2016), amelyet nevezhetünk mentori szerepben való jártasságnak is (St. Jean - Audet, 2009). Ezen tapasztalatok több forrásból érkezhetnek, az ehhez szükséges kompetenciák és eszközök, módszerek elsajátíthatók képzések során, de azokat a gyakorlatban is feltétlen szükséges alkalmazni, hogy eredményesen, és a lehető legjobb eredmény elérése mellett vonják be őket. Goleman (2006) a tapasztalatok - legyen az adott iparágból származó, vagy általános - mellé beemeli az üzleti és szakmai tudást is, amelyet St. Jean és Audet (2009) is támogat. Minden bizonnyal e tényezők megléte szükségszerü a sikeres folyamatvezetéshez, hiszen üzleti szemléletű tevékenységet végezni gazdasági és üzleti ismeretek nélkül nem lehet. Ugyanakkor átgondolandó, hogy ezen
Fenti okfejtésből kiindulva az iparági tapasztalat és az üzleti ismeretek egymás kiegészítőjeként jelennek meg. Amennyiben figyelembe vesszük e tényezőkre adott átlagos értékeket is, az állapítható meg, hogy a teljes mintán vizsgálva a gazdasági ismeretek fontosság, azaz elvárás szempontjából nézve 4,21-es átlagértéket kaptak, amelylyel az abszolút rangsorban a 14. helyen állnak a tényezők között, míg az adott iparágban szerzett tapasztalat 3,71-es átlagértékkel az utolsó, legkevésbé jelentős tényezőnek ítélt, 20. pozíciót foglalja el. Mentorok esetén sem sokkal másabb a kép: 3,949-es (17. hely) fontossági érték gazdasági és üzleti ismeretek terén, és 3,61-es eredmény (20. hely) adott iparági tapasztalat esetén. A mentoráltak a gazdasági ismereteket a 10 . helyre pozícionálták 4,23as értékkel, míg az iparági tapasztalatot 3,76-os értékkel szintén a legkevésbé fontos tényezőnek titulálták. $\mathrm{Az}$ adott válaszok és a vállalkozásfejlesztési mentorálási folyamattal szemben támasztott követelmények értelmében a két tényező a megkérdezettek szerint együtt mozog, azaz egymás kiegészítőjeként jelenik meg, de abszolút fontosságukat tekintve eltérnek, az adott iparágban szerzett tapasztalat meglétét nem tartják jelentősnek, így a H1 hipotézist elfogadtam.

\section{A 'holisztikus látásmód' faktor}

A faktor három tényezőt foglal magában: a folyamat során tanúsított holisztikus személetet (1), a folyamat- (2) és célorientáltságot (3).

A holisztikus szemlélet és rendszerben történő gondolkodás magában foglalja annak a képességét, hogy a mentor képes megállapítani és kialakítani azt a távolságot az ügyfél és önmaga között, ami biztosítja a megfelelő a bizalmi légkör létrejöttét a szükséges információk átadásához, de mégsem túl közeli, azaz megfelel a konstruktív 
és proaktív visszajelzések adásához szükséges elvárásoknak. Ugyanakkor feltételezi, hogy a mentor képes az adott kérdésre és elakadásra, mint egy rendszer elemére tekinteni, amely során feltárja az ok-okozati viszonyokat és összefüggéseket egyes tényezők között. E látásmód biztosításához nagymértékben hozzájárulhat az ötödik faktor tartalma, ugyanis a teljes kép kialakításához feltétlen szükséges korábbi tapasztalat és üzleti, gazdasági elméleti ismeret is.

Magára a mentorálási folyamatra, annak fókuszára a cél- és folyamatorientáltság lesz jellemző, hogy a keretek meghatározása során kitüzött célokat elérjék, mindezt úgy, hogy a folyamat során a mentor inkább tartja ekvivalenciában azt, miként éli meg a mentorált a folyamatot. Ennek során egy egyensúlyi állapot elérésére törekszik, ami még biztosítja a célok felé történő elöre mozdulást úgy, hogy közben figyel a mentorált igényeire, érzéseire, azaz a folyamat részleteire is. Habár a vállalkozásfejlesztési mentorálási folyamattal szemben többszörösen is elvárt a közösen kitűzött célok elérése, mégsem jelenik meg a faktorok között a projektorientált szemlélet, azaz, hogy a mentor és mentorált kapcsolata meghatározott időszakra, meghatározott erőforrások felhasználásával, meghatározott céllal jön létre, amely iránt elkötelezettséget és céltudatosságot feltételez a mentor részéről. Ezen utóbbi tényező az integritás, az empátia és a benchmarking tényezőjével egyetemesen egyik faktorban sem szerepel.

\section{A kutatás korlátai és tanulságai}

A kutatás során beazonosításra került néhány korlát, mint a longitudinalitás hiánya, a személyes szürők figyelmen kívül hagyása, a változók száma és cizelláltsága, a szerepkettősség nem megengedettsége, valamint a megtapasztalt folyamat eredményességi szempontú megítélésének elmulasztása. Korlátként nevezhető meg továbbá, hogy nehezen definiálható, mikor beszélhetünk 'vegytiszta' mentorálási folyamatról, illetve mely esetekben keveredik a vezetőfejlesztés más irányzataival a segítő tevékenység, esetlegesen családi és személyes kötelékek hogyan befolyásolják az elvárásokat. A kutatás ugyanakkor nem különbözteti meg azokat a mentorálási folyamatokat, amelyek csak és kizárólag egyénre vonatkoznak azoktól, amelyekben csapatok számára történik a segítségnyújtás.

Jövőbeni kutatási irányként definiálható a vállalkozásfejlesztési mentorálási folyamatok szisztematikus osztályozása és kategorizálása, valamint az ezekhez kapcsolódó elvárások diverzifikálása, a kapcsolat sikerességének vizsgálata, a folyamatban résztvevők nemi összetételének áttekintése, valamint a sikertelen folyamatokhoz kapcsolódó ok-okozati összefüggések feltérképezése. A feltáró kutatás további, jövőbeni irányát jelenthetné annak a vizsgálata is, hogy megfigyelhetők-e eltérések a folyamattal szembeni elvárásokban aszerint, a mentorált első vállalkozásának fejlesztéséhez kér-e segítséget vagy többszörös vállalkozó, befolyásolja-e az esetleges rokoni viszony a mentor-mentorált kapcsolatát és ezáltal magát a folyamatot, megfigyelhetők-e különbségek aszerint, hogy mi a folyamatba érkezés oka.

\section{Összefoglalás}

Annak érdekében, hogy a vállalkozásfejlesztési mentorálási folyamatok bizonyos fokig standardizáltak legyenek, megfelelö képzettségű és felkészült mentorok facilitálják azokat, szükséges egy check-list felállítása, amely hozzájárul a sikeres és hatékony vállalkozásfejlesztési mentorálási folyamat vezetéséhez. A kutatásban részt vettek Magyarországon lefolytatott, vállalkozásfejlesztési mentorálási folyamatokban szerzett tapasztalatain alapuló eredmények, és az azokon alapuló faktorelemzés segítségével egy olyan hat tényezőt kombináló modellt állítottak össze, amely elősegíti a kitüzött célok elérését. A vállalkozásfejlesztési mentorálási tevékenység sikeres és eredményes vezetését elősegítő hat tényezős modell elemei: a mentorált megértésének képessége (1), a folyamatvezetési kritériumok kialakításának képessége (2), a bizalom teremtésének kompetenciája (3), a változás támogatásának képessége (4), valamint a hard ismeretek (5) és a holisztikus látásmód (6) megléte. A bemutatott modell önmagában nem jelenti, jelentheti a siker zálogát, hiszen egy bonyolult, többkomponensű rendszer, egyik folyamatának vezetését támogató kompetenciákat, attitüdöket és elvárásokat mutatja be strukturálva. Első lépésnek azonban tekinthető abban az értelemben, hogy szükség mutatkozik a vállalkozásfejlesztési mentorálási folyamat, mint tevékenység definiálására és az ezzel kapcsolatos elvárásrendszer megalkotására, a folyamat egyfajta standardizálása és ezáltal minőségbiztosítási rendszerének kialakítására. A bemutatott modell mentén a jövőben pedig akár a folyamatok sikeressége is vizsgálható lehet.

\section{Felhasznált irodalom}

Alfred, G. - Garvey, B. (2010): Mentoring Pocketbook (3rd edition). Alresford: Management Pocketbook Ltd.

Baumol, W.J. (1968): Entrepreneurship in economic theory. The American Economic Review, 58 (2) p. 64-71.

Belcourt, M. - Wright, C.P. - Saks, M.A. (2000): Managining Performance through Training and Develoment. Ontario: Nelson Thomson Learning

Bencsik, A. (2012): Tacit tudás átadás mentoring rendszer oktatási intézményekben http://webcache.googleusercontent.com/ s e a r c h? q = c a c he:s 8 r C f x j fd W Y J : w w w. tudasmenedzsment.org/tudmenmuhely2012/ d o c s / P r of D r_ B e n c sik_ A n d r e a . $\mathrm{ppt}+\& \mathrm{~cd}=8 \& \mathrm{hl}=\mathrm{en} \& \mathrm{ct}=\mathrm{clnk} \& \mathrm{gl}=\mathrm{hu} ;$ Olvasva: 2016 . szeptember 22 .

Berman, E.M. - West, J.P. (2008): Managing Emotional Intelligence in U.S. Cities: A Study of Social Skills among Public Managers. Public Administration Review, 68 (4) p. 105-112. https://doi.org/10.1111/ j.1540-6210.2008.00912.x

Bisk, L. (2002): Formal entrepreneurial mentoring: the efficacy of the third party managed programs. Journal of Career Development Internationl 7 (5) p. 262-270. DOI 10.1108/13620430210440082 
Bolden, R. (2009): Leadership Development in SMEs: Designing a customised solution; Centre for Leadership Studies, University of Exeter. https://ore. exeter.ac.uk/repository/bitstream/handle/10036/32273/ bolden11.pdf?sequence $=1 \&$ isAllowed=y Olvasva: 2017 . március 20.

Bolden, R. - Terry, R. (2000): Leadership Development in Small and Medium Sized Entrepreises. Phase 1 Report. Centre for Leadership Studies, University of Exeter. http://business-school.exeter.ac.uk/documents/ discussion_papers/cls/SME1.pdf Olvasva: 2017. március 20.

Chuck, E. - Yanbo, W. (2014): The Effect of Mentoring in Entrepreneurial Carrer Choice. http://funginstitute.berkeley.edu/wp-content/ uploads/2014/09/Chuck_Eesley_Paper1.pdf Olvasva: 2016. augusztus 24 .

Covey, S.R. (2004): A kiemelkedően sikeres emberek 7 szokása - az önfejlesztés kézikönyve. Budapest: Bagolyvár Kiadó

Clutterbuck, D. (2005): Establishing and Maintaining Mentoring Relationships: An Overview of Mentor and Mentee Comptenecies. SA Journal of Human Resource Management, 3. (3) p. 2-9. https://doi.org/10.4102/ sajhrm.v3i3.70.

Clutterbuck, D. - Lane, G. (2007):The situational mentor. London, Gower: Aldershot

Clutterbuck, D. - Kochan, F.K. - Lunsford, L. Dominguez, N. - Haddock-Millar, J.(2017): The SAGE Handbook of Mentoring. New York: Sage DOI: http:// dx.doi.org/10.4135/9781526402011

Conor, M. (2007): Coaching and mentoring at work. Berkshire: OpenUni Press, MacGraw-Hill Education

Csapó, K. (2004): A gyorsan növekvő kis- és középvállalkozások jellemzői és fejlesztési lehetőségei Magyarországon. Budapest: Budapesti Corvinus Egyetem, Kisvállalkozás - fejlesztő Központ, Gazdálkodástani Ph.D. Program

Dávid, M. - Gefferth, É. - Nagy, T. - Tamás, M. (2014): Mentorálás a tehetésggondozásban. Budapest: Magyar Tehetségsegtő Szervezetek Szövetsége

DeLong, T.J. - Gabarro, J.J. - Lees, R.J. (2008): Why Mentoring Matter in a Hypercompetitive World. Harvard Business Review 86 (1) p.115-121.

Dickinson, K. - Jankot, T. - Gracon, H. (2009): Sun Mentoring - 1996-2009. Sun Microsystems: http:// research.sun.com/techrep/2009/smli_tr-2009-185.pdf Olvasva: 2017. január 30.

Filius, Á. (2012): A sikeres vállalati mentoring alapjai. http://www.hrportal.hu/hr/a-sikeres-vallalatimentoring-alapjai-20120216.html Olvasva: 2017. január 9.

Fulmer, R.M. - Gibbs, P.A. - Goldsmith, M. (2000): Developing Leaders: How Winning Companies Keep On Winning. Sloan Management Review, 42 (1), p. 49-59. https://doi.org/10.1108/ICT-06-2017-0039.

Füstös, L. - Kovács, E. - Mészéna, G. - Simonné M., N. (2007): Alakfelismerés: Sokváltozós statisztikai módszerek. Budapest: Új Mandátum Könyvkiadó
Gaál, Z. - Szabó, L. - Obermayer-Kovács, N. - Csepregi, A. (2012): Middle Managers' Maturity of Konwledge Sharing: Investigation of Middle Managers Working at Medium- and Large-sized Entreprises. The Electronic Journal of Knowledge Management, 10 (1) p. 26-38.

Garringer, M. (2015): Elements of Effective Practicr for mentoring - Research-informed and practitionerapproved best practices for creating and sustaining impactful mentoringrelations and strong program services, 4th edition. Boston: The National Mentroing Partnership

Gay, B. - Stephenson, J. (1998): The mentoring dilemma; guidance and/or direction? Metroring and Tutoring Partnership in Learning, 6. (1-2) p.43-54. https://doi. org/10.1080/0968465980060104

Goleman, D. (1996): Emotional Intelligence. London: Bloomsbury

Heathfield, S. M. (2016): 15 Characteristics of a Successful Mentor - Who Makes an Effective Mentor? The Balance - Humans Resources Magazin. https://www. thebalance.com/top-characteristics-of-a-successfulmentor-1917831 Olvasva: 2016. szeptember 21.

Heidrich, B. (2006): Szolgáltatásmenedzsment. Budapest: Human Telex Consulting

Hollister, L. R. - Sutter, C. (2001): Facilitating Authenticity - Open communication about tough issues can deepen your relationship. Creer Resource Centre; http:// www.ache.org/newclub/CAREER/MentorArticles/ Authenticity.cfm Olvasva: 2017. január 17.

Iniguez, S. (2008): Leadership and Learning are Indispensible to Each Other'-JFK; http://humanities. blogs.ie.edu/2008/02/leadership-and-learning-areindispensable-to-each-other-jfk.html Olvasva: 2016. november 20.

Johnes, G. - Spooner, K. (2006): Coaching high achievers. Consulting Psychology Journal, Practice and Research, 58 (1), p. 40-50. http://dx.doi.org/10.1037/1065-9293.58

Kahn, W. A. (1998): Caring for the caregivers: Patterns of organizational caregiving. Administrative Science Quarterly, 38 (4), p. 539-563.

Kantor, P. (2013): Promoting Women's Entrepreneurship Development based on Good Practice Programmes: Some Expericences from the North to the South. Geneva: Official Publication of International Lebour Office

Katherndahl, D.A. - Longo, D.R. - Griswold, K. (2011): Issues Important to the Research Mentoring Relationship, Family Medicine, 43 (3), p.193-197.

Kállay, L. -Imreh, Sz. (2004): A kis- és középvállalkozásfejlesztés gazdaságtan. Budapest: Aula Kiadó

Kerry, T. - Mayers, A. S. (2013): Issues in Mentoring. New York: Routledge Taylor and Francis Group

Kram, K. E. (1985): Mentroing at Work. Glenview: Foresman

Krueger-Wilson, C. (1998): Mentoring the entrepreneur. Nursing Administration Quarterly, 22 (2), p.1-12.

Kunos, I. (2011): A coaching HRM-ben való alkalmazásának lehetőségei. Humánpolitikai Szemle, 22 (11), p. 51-57. 
Lefebre, M.R. - Redien-Collot, R. (2013): How to do Things with Words: The Discursive Dimension of Experimental Learning in Entrepreneurial Mentoring Dyads. Journal of Small Business Management, 51 (3), p. 370-393. http://dx.doi.org/10.1111/jsbm.12022.

Leith, C.M. - MsMullan, C. - Harrison, R.T. (2009): Leadership development in SMEs: an action learning approach. Action Learning: Research and Practice, 6 (3), p.243-263. https://doi. org/10.1080/14767330903299464.

Lutz, B. - Hixom C. - Paretti, M.C. - Epstein, A - Lesko, A. (2015): Mentoring and Facilitation in Entrepreneurship Education: Beliefs and Practices. The Journal of Engineer Entrepreneurship, 6 (1), p. 38. DOI: 10.7814/ jeenv6p4.

McCauley, C.D. - VanVelsor, E. (2004): The center for creative leadership handbook of leadership development, New Yersey: John Wiley \& Sons in Chuck, E. - Yanbo, W. (2014): The Effect of Mentoring in Entrepreneurial Carrer Choice. http://funginstitute. berkeley.edu/wp-content/uploads/2014/09/Chuck Eesley Paper1.pdf; Olvasva: 2016. augusztus 24.

Megginson, D. - Clutterbuck, D. - Garvey, B. - Strokes, P. - Garret-Harris, R. (2005): Mentoring in action: a practical guide. London: Kogan Page

Memon, J. - Abd Rozan, M.Z. - Uddin, M. - Daud, D. (2013): Selecting a Mentor: Guide for a Protégé. World Applied Sciences Journal, 24 (6), p. 732-738. DOI: 10.5829/idosi.wasj.2013.24.06.1106

Menges, C. (2015): Toward Improving the Effectiveness of Formal Mentoring Programs, Matching by Personality Matters, SAGE Publications. DOI: 10.1177/1059601115579567 http:/gom.sagepub. com/content/41/1/98.full.pdf+html Olvasva: 2016. szeptember 18 .

Mitchell, M.E. - Eby, L.T. - Ragins, B.R. (2015): Мy mentor, my self: Antecendents and outcomes of perceived similarity in mentoring relationships. Journal of Vocational Behaviour, 89 (1) p.1-9. DOI 10.1016/j.jvb.2015.04.008.

Mullen, E. J. (1994): Framing the mentoring relationship as an information exchange. Human Resource Management Review, 4 (9), p.257-281. DOI 10.1016/1053-4822(94)90015-9.

Mumford, A. (1995): Learning and mentoring. Industrial and Commercial Training, 27 (8), p.4-7. https://doi. org/10.1108/00197859510097045.

Myers, C. (2016): Mentorship Is Key To Career Success For Young Professionals. http:/www.forbes.com/sites/ chrismyers/2016/02/21/mentorship-is-key-to-careersuccess-for-young-professionals/\#d1380b370910 Olvasva: 2017. január 16.

Nagypál, M. (2010): Szempontok a jó mentor kiválasztásához.

http://www.hrportal.hu/hr/szempontok-a-jo-mentorkivalasztasahoz-20100316.html. Olvasva: 2016. július 23.

Noor, M. (2010): Mentors as Role Models; Duke - The Graduate School. https://gradschool.duke.edu/ professional-development/mentoring/what-mentor/ mentors-role-models Olvasva: 2017. január 17.

Palmer, L. (2016): Authenticity in Mentoring. Arisona: Maricopa

Petrányi, $V$. (2013): Melyik az eredményes vezetőfejlesztési módszer? http://www.hrportal.hu/hr/vezetofejlesztesvagy-vezetojavitas-20080416.html Olvasva: 2016. augusztus 24.

Philipps-Jones, L. (2000): New Mentors \& Protégés: How to Suucceed with the New Mentoring Partnerships. Crass Valley: Coalition of Counseling Centers

Rae, D. (2000): Understanding entrepreneurial learning: a question of how? International Journal of Entrepreneurial Behaviour \& Research, 6 (3), p.145159. https://doi.org/10.1108/13552550010346497.

Rácz, I. (2014): Tudás menedzselése a kiemelkedő szellemi munkavállalók körében. http://kgk.sze.hu/ images/dokumentumok/kautzkiadvany2014/Racz\%20 Irma.pdf Olvasva: 2016. szeptember 22.

Ragins, B. R. (1997): Diversified mentoring relationships in organizations: A power perspective. Academy of Management Review, 22 (2), p.482-521. DOI:10.5465/ AMR.1997.9707154067.

Ries, E. (2011) Lean Startup. Budapest: HVG Könyvkiadó Robinson, P. - Haynes, M. (1991): Entrepreneurship education in America's major universities. Entrepreneurship Theory and Practice, 15 (3), p.41-67.

Rooke, D. - Torbert, W. (2005): A vezetői képesség átalakulása. Harvard Business Manager, 7 (7-8), p. 6-17.

Roll, M. (2015): Ten Ways to Become a Great Mentor. http://knowledge.insead.edu/blog/insead-blog/tenways-to-become-a-great-mentor-3994 Olvasva: 2017. janár 10.

Sajtos, L. - Mitev, A. (2007): SPSS kutatási és adatelemzési kézikönyv. Budapest: Alinea

Savaneviciené, A. - Stukaité, D. - Silingiené, V. (2008): Development of Strategic Individual Competences. Engineering Economics, 58 (3), p. 81-88.

Smallbone, D. - Baldock, R. - Bridge, M. (1998): Targeted Support for New and Young Businesses: The Case of North Yorkshire TEC's 'Backing Winners' Program. Journal of Small Business and Enterprise Development, 5 (3), p.199-207. https://doi.org/10.1108/ EUM0000000006777.

Smith, J. (2013): How To Be a Great Mentor? http://www. forbes.com/sites/jacquelynsmith/2013/05/17/how-tobecome-a-great-mentor/\#212e6a61449e, Olvasva: 2016. augusztus 6 .

Smith-Jenetsch, K.A. - Scielzo, S.A. - Yarbrough, C.S. Rosopa, P.J. (2008): A comparison of face-to-face and electronic peer-mentoring: Interactions with mentor gender. Journal of Vocational Behavior, 72 (2), p.193206. https://doi.org/10.1016/j.jvb.2007.11.004.

St. Jean, E. - Audet, J. (2009): The role of mentoring in the learning development of the novice entrepreneur. International Entrepreneurial Journal, 8 (1), p.119-140. https://oi.org/10.1007/s11365-009-0130-7 
St. Jean, E. - Audet, J. - Couteret, P. (2009/b): Factors Leading to Satisfaction in a Mentoring Scheme for Novice Entrepreneurs. International Journal of Evidence Based Coaching and Mentoring, 7 (1), p.148 $-157$.

Stracevich, M.M. (2009): Characteristics of the Most Effective Mentors. Center of Coaching and Mentoring. http://www.coachingandmentoring.com/ Characteristics OfMostEffectiveMentor.html Olvasva: 2016. augusztus 6.

Szádvári, L. (2011): Új utakon, avagy a coaching titkai. Humánpolitikai Szemle, 22 (5), p.42-45.

Terjesen, S.-Sullivan, S.E.(2011): Therole ofdevelopmental relationships in the transition to entrepreneurship: A qualitative study and agenda for future research. Career Development International, 16 (5), p.482-506. https://doi.org/10.1108/13620431111168895.

Vecsenyi, J. - Petheö, A. (2017): Vállalkozz okosan! Budapest: HVG Kiadó.

Waters, L. - McCabe, M. - Kiellerup, D. - Kiellerup, $S$. (2012): The role of formal mentoring on business success and self-esteem in participation of new business start-up program. Journal of Business and Psychology, 17 (1), p.107-121. http://dx.doi. org/10.1023/A:1016252301072.

Zsigmond, Sz. (2011): A sportpszichológia módszereinek alkalmazási lehetőségei a business coachingban. Budapest: Budapesti Gazdasági Főiskola, szakdolgozat

Zsigmond, Sz. - Tasi, P. (2016): Mentoring Behind the Scenes - Skills and Competences of an Effective Entrepreneurial Mentor. 9th International Conference of Education, Research and Innovation, Proceedings, ISBN: 978-84-617-5895-1.

Zsigmond, Sz. (2017): F.A.I.L, First Attempt In Learning, avagy mit és hogyan tanulhatunk a sikertelen vállalkozásfejlesztési mentorálási folyamatokból? Pécs: ICUBERB (International II. International Conference on University-Based Entrepreneurship and Regional Development: Theory, Empirics and Practical Implementation) Book of Papers. ISBN 978963-429-212-8 